\title{
Pool Therapy to Reduce Aggressive Behavior of Autistic Children
}

\author{
Aldjon Nixon Dapa \\ Department of Special Education \\ Universitas Negeri Manado, Indonesia \\ aldjondapa@unima.ac.id.com
}

\author{
Henny B. A. Kiriweno \\ Principal at Paulus Special School in Tomohon \\ North Sulawesi, Indonesia \\ hennykiriweno@gmail.com
}

\begin{abstract}
The purpose of this study is to get an overview and the extent to which the effectiveness of the application of pool therapy methods in reducing aggressive behavior in children with autism. This study uses experiments in the form of Single Subject Research (SSR), with A-B-A research design research subjects are autistic children who have excessive aggressive behavior, by applying the pool therapy method which is part of Hydrotherapy. The results showed that the application of the pool therapy method can reduce aggressive behavior in class IV autistic students at the Paulus Special School in Tomohon. Pool Therapy can be used as an alternative model of intervention to relax, relieve pain, relax tense muscles, and as a means of recreation for children with autism. The aggressive behavior of autistic children such as rebelling, throwing, hitting, and damaging things around, even hitting the teacher, can be reduced or even eliminated by this intervention model.
\end{abstract}

Keywords: autistic children, aggressive behavior, pool therapy methods

\section{INTRODUCTION}

An autistic child is a child who has a nervous system development disorder that causes children to experience social interaction, communication, and behavioral disorders. Autistic is a complex developmental disorder involving communication, social interaction and imagination activities. Symptoms begin to appear before the child is 3 years old (Suryana, 2004).

Based on observations at SLB Paulus Tomohon, the author found a student who still had high aggressive behavior while in class. The characteristics of these children are hyperactive, easily bored, and like new things. The autistic student often injures himself by hitting his head, damaging things around etc. Aggressive behavior appears when the child is ordered to write, but the child refuses but the teacher continues to instruct the child to write. Then the child's resistance appears accompanied by anger and aggressive behavior, (rebelling, throwing, hitting, and damaging things around, even hitting the teacher).

Some aggressive behaviors such as hitting, shouting, not wanting to follow orders, crying and damaging can inhibit affective domains such as Receiving / Attending, for example, listening to the opinions of others. Because aggressive behavior (not willing to follow orders) can overrule the affective domain.

The child's aggressive behavior will diminish if he has gotten something he wants or something he likes. Things that autistic children like can be toys, food, and even water. Pool therapy is a method of treatment and healing using water to get the effects of the therapist. With Pool therapy, autistic children will be able to control their behavior while in the water.

\section{METHOD}

This study uses a single subject research single subject research) or SSR which includes experimental research that focuses more on individual scores or performance than on group performance (Sunanto, 2005).
SSR is suitable for use in special education research for implementing procedures or behavior modification strategies in children with special needs with limited abilities (severe handicaps) (Homer, 2005).

The SSR design used is A-B-A design. The target of eliminating aggressive behavior is noted in the condition of Baseline A1 for a certain period of time and this is done in the condition of intervention B. After measuring the behavior in condition $\mathrm{B}$, do the behavior measurement in the second baseline condition (A2). The subject of the study was an autistic child in SLB Paulus Tomohon who had excessive tantrums and aggressive behavior.

\section{RESULT AND DISCUSSION}

A. Results

1. Baseline Measurement Results (A1)

In a period of 5 days, the frequency of the incidence of $\mathrm{R}$ performing aggressive behavior was 36 times. The frequency of occurrence of aggressive behavior that changes is influenced by the situation and conditions in the environment around $\mathrm{R}$.

The purpose of the analysis of the results of this baseline is to find out how often the aggressive behavior of $\mathrm{R}$ appears, which has been identified by researchers as changing aggressive behavior. In the first session aggressive behavior that appears 1 time, in the second to fifth session always changes between 2 times and 3 times.

\section{Intervention Measurement Results (B)}

The Intervention B Phase was carried out in 10 sessions, all of which were carried out after school and took place in the swimming pool of the Minahasa Hotel in Manado and the allocation of the intervention time was approximately 60 minutes from 14.00 Eastern Indonesian Time to 15.30 Eastern Indonesian Time. Researchers carry out intervention steps in accordance with those that have been prepared and planned in advance. 
By using the application of Pool therapy intervention, it can be seen that the development is quite satisfying in $\mathrm{R}$ who do not engage in aggressive behavior very often. It can be seen that the results of interventions given to $\mathrm{R}$ can help reduce aggressive behavior. However, looking back there are several factors that influence the emergence of aggressive behavior.

Baseline 2 Measurement Results (A2). The baseline phase 2 is the final data after the intervention and is a repetition of the baseline phase 1 . This stage is done by researchers only to see how the development of aggressive $\mathrm{R}$ behavior after no intervention has been carried out.

\section{B. Discussion}

Based on the research data that has been presented on the graph of aggressive behavior along with an analysis of the results of the research that has been presented, it illustrates that the reduced aggressive behavior of autistic children in the Hezekiah Manado Autistic Special School can be handled appropriately by the efforts and cooperation of all relevant parties and the selection of procedures right. Then obtained valid results that the application of pool therapy methods can reduce aggressive behavior in children with autism.

This is evident from the results of the data graph that is in the direction of the tendency of condition (A) baseline 1 . The most aggressive behavior appears 8 times and at least 7 times. Whereas in condition (B) after being given an intervention using the pool therapy method the direction of a child's aggressive behavior tends to decrease compared to the baseline condition 1 . The result of the most aggressive behavior that appears can be seen at the intervention stage of the sixth session, which is as much as 6 times and that too because $\mathrm{R}$ is still adapting to the surrounding environment. Furthermore, the aggressive behavior of $\mathrm{R}$ appeared 5 times in the seventh, eighth, ninth, and thirteenth sessions. And aggressive behavior that appears at least 4 times in the tenth, eleven, twelve, fourteen and fifteen sessions. The tendency toward demand marked by the achievement of the percentage A2 up to $40 \%$ compared to the condition of A1 $80 \%$ with a comparison of the results of the final results in each condition A1 the results of the final result 7, B the final results 4, and $\mathrm{A} 2$ the results of the final results 2 .

\section{CONCLUSION}

Aggressive behavior in children with autism (R) in the initial condition before being given an intervention using the pool therapy method that is fairly high, this can be seen from the acquisition of the mean level at the initial condition / baseline 1 (A1) of 7.2, the effect of the stability of $80 \%$ (stable). Aggressive behavior in children with autism (R) after being given an intervention using the pool therapy method that is decreased from the initial condition / baseline 1 (A1), this can be seen from the acquisition of the mean level at baseline 2 (A2) by 4.6 with a percentage $40 \%$ trend stability states unstable (variable).

\section{REFERENCES}

[1] Mangunsong, F. (2009). Psikologi dan Pendidikan Anak Berkebutuhan Khusus. Depok : LPSP3 UI.

[2] Maulana. M. (2007). Mendidik Anak Autis Dan Gangguan Mental Lain Menuju Anak Cerdas Dan Sehat. Katahati. Yogyakarta.

[3] Peeters, T, (2004). Autise, Hubungan Pengetahuan Teoritis dan Intervensi Pendidikan Bagi Penyandang Autis. Jakarta: Dian Rakyat.

[4] Tombokan R., 2008. Applied Behavior Analysys (Modifikasi Perilaku). Manado: Universitas Negeri Manado.

[5] Pusat Pendidikan Tenaga Kesehatan DepKes RI, 1993 Sumber Fisis. Buku Pegangan Kuliah Program DIII Fisioterapi, Surakarta

[6] Joko Yuwono. 2012. Memahami Anak Autistik (Kajian Teoritik dan Empirik). Bandung: Alfabeta.

[7] Tombokan, R., \& Usman Duyo. 2008. Metodologi Penelitian. Manado: Universitas Negeri Manado.

[8] Suryana, A. 2004. Terapi autisme, anak berbakat dan anak hiperaktif. Jakarta: Progres.

[9] Sunanto, J., Takeuchi, K., \& Nakata, H. (2005). Pengantar penelitian dengan subjek tunggal. Crice: Universitas Tsukuba. 